\title{
Syntheses and Synergistic Activity of Some Pyrethrum Synergists from Dillapiole
}

\author{
Sarman S. Tomar, Mohan L. MAHeShwari* \\ and Sunil K. MukerJeE \\ Division of Agricultural Chemicals, ${ }^{*}$ Indian Agricultural Research Institute, \\ New Delhi-110012 (India) \\ Received January 8, 1979
}

\begin{abstract}
In a search for alternative pyrethrum synergists, dillapiole, one of the chief constituents of Indian dill (Anethum sowa Roxb.) seed oil has been converted into a number of derivatives. Syntheses of 16 such compounds, their spectrometric characterization and factors of synergism towards pyrethrins against Tribolium castaneum Herbst. are being reported. Some of these compounds showed superior activity to piperonyl butoxide, the most commonly used pyrethrum synergist.
\end{abstract}

Synergists play an important role in economic and practical formulations of pyrethrum. Most of the commercial methylenedioxyphenyl (MDP) synergists like piperonyl butoxide, ${ }^{1)}$ sulfoxide ${ }^{2)}$ and $n$-propyl isome $^{3)}$ are manufactured from safrole, a natural product of limited supply. In an attempt to find an alternative source for pyrethrum synergists, Gulati and Parmar ${ }^{4}$ discovered the synergistic properties of dillapiole (I), a major constituent ( $27 \%$ ) of Indian dill (Anethum sowa Roxb.) seed oil. It was also found to have synergistic action for N-methyl carbamates by Lichtenstein et al. ${ }^{51}$ and Tomar et al. ${ }^{6 \prime}$ (1978). Dillapiole, being a natural compound, is also limited in supply and it would be desirable to enhance its value by preparing more potent derivatives from it. With such an objective, the synthesis of a number of simple derivatives of it has been tried. ${ }^{7,8)}$ In this paper we report the synthesis of new pyrethrum synergists from dillapiole, some of which are quite promising.

\section{EXPERIMENTAL}

Synthesis. All melting and boiling points are un-

* Present address: National Bureau of Plant Genetic Resources, I.A.R.I. Campus, New Delhi110012 (India).

** Contribution No. 155. corrected. TLC was done with silica gel-G and visualised by charring with dil. $\mathrm{H}_{2} \mathrm{SO}_{4}$. IR spectra were recorded on Perkin Elmer-457 spectrophotometer. NMR spectra were recorded in $\mathrm{CDCl}_{3}$ on Varian A-60 spectrometer using TMS as the internal reference. Mass spectra was recorded on CEC 21-110 mass spectrometer at $70 \mathrm{eV}$. All compounds were purified by column chromatography followed by crystallization wherever possible.

Dillapiole (I) was isolated from commercial dill oil as reported earlier. ${ }^{\text {) }}$ Isodillapiole (II), dihydrodillapiole (III) and the bromo derivatives IV and $V$ were prepared by literature procedure. ${ }^{\mathrm{a}, 10)}$

1-(2, 3-Dimethoxy-4, 5-methylenedioxyphentyl)-1, 2dibromopropane (VI). Prepared by addition of bromine $(1.6 \mathrm{~g})$ in dichloromethane to isodillapiole (II, $2.2 \mathrm{~g}$ ) in the same solvent at room temperature, this dibromoderivative $(2.2 \mathrm{~g})$ came out as colourless needles from acetic acid, mp $109 \sim 110^{\circ} \mathrm{C}$. Anal. Found: C, 38.1; H. 3.6; $\mathrm{Br}$, 41.4. Calcd. for $\mathrm{C}_{12} \mathrm{H}_{14} \mathrm{Br}_{2} \mathrm{O}_{4}$ : C, $37.7 ; \mathrm{H}, 3.7 ; \mathrm{Br} 41.9 \%$.

2, 3-Dimethoxy-4, 5-methylenedioxy-6-bromopropylbenzene (VII). Prepared by addition of bromine $(3.3 \mathrm{~g})$ in dichloromethane to dihydrodillapiole (III, $4.5 \mathrm{~g})$, this bromo-derivative $(4.8 \mathrm{~g})$ was obtained as a colourless liquid, bp $116 \sim 17^{\circ} \mathrm{C} / 0.1 \mathrm{~mm}$. Absence of aromatic proton in NMR spectrum agrees with structure VII. Anal. Found: C, 47.1; H, 4.8; Br, 26.3. Calcd. for $\mathrm{C}_{12} \mathrm{H}_{15} \mathrm{BrO}_{4}$ : C, $47.5 ; \mathrm{H}, 5.3 ; \mathrm{Br}, 26.4 \%$.

3-(2, 3-Dimethoxy-4, 5-methylenedioxyphenyl)-1, 2dithiocyanopropane (VIII). Thiocyanogenation of dillapiole $(\mathrm{I}, 4.5 \mathrm{~g})$ in $\mathrm{CCl}_{4}(200 \mathrm{~m})$ by the method of Wood and Fieser ${ }^{11}$ gave VIII which crystallised from acetic acid as light yellow needles $(4 \mathrm{~g}), \mathrm{mp} 75 \sim 76^{\circ} \mathrm{C}$, 
$\nu_{\mathrm{In} x}^{\mathrm{CCl}} 2160$ and $2040 \mathrm{~cm}^{-1}(-\mathrm{SCN})$. Anal. Found: $\mathrm{C}$, $55.2 ; \mathrm{H}, 5.0 ; \mathrm{N}, 9.5 ; \mathrm{S}, 10.4$. Calcd. for $\mathrm{C}_{14} \mathrm{H}_{14} \mathrm{~N}_{2} \mathrm{O}_{2} \mathrm{~S}_{2}$ : C, $54.9 ; \mathrm{H}, 4.6 ; \mathrm{N}, 9.2 ; \mathrm{S}, 10.5 \%$. NMR: $2.6-3.67$ ( $5 \mathrm{H}, \mathrm{m}$, side chain protons), $4.05\left(3 \mathrm{H}, \mathrm{s}_{3} \mathrm{OCH}_{3}\right), 4.14$ ( $\left.3 \mathrm{H}, \mathrm{s}, \mathrm{OCH}_{9}\right), 6.11$ ( $2 \mathrm{H}, \mathrm{s}$, methylenedioxy protons), $6.54(1 \mathrm{H}, \mathrm{s}$, aromatic proton).

2, 3-Dimethoxy-4, 5-methylenedioxy-6-chloromethyl propylbenzene $(I X)$. Dihydrodillapiole (III, $2.5 \mathrm{~g}$ ) in dry ether $(20 \mathrm{ml})$ was added dropwise with stirring to a solution of $\mathrm{ZnCl}_{2}$ (500 $\mathrm{mg}$ ) in methyl chloromethyl ether $(10 \mathrm{ml})$ during $30 \mathrm{~min}$. and the mixture was poured into ice water. It was extracted with ether and purified by column chromatography over silica gel $(50 \mathrm{~g})$. Elution first with petroleum ether gave some dimeric matter. Elution next with benzene gave the product $(0.6 \mathrm{~g}, 20 \%)$ which crystallised from petroleum ether as colourless needles, mp $85^{\circ}$. It gave a positive test with alcoholic $\mathrm{AgNO}_{3}$. Anal. Found: C, 57.7; $\mathrm{H}, 6.4 ; \mathrm{Cl}, 12.8 . \mathrm{C}_{13} \mathrm{H}_{17} \mathrm{ClO}_{4}$ requires $\mathrm{C}, 57.2 ; \mathrm{H}, 6.2$; $\mathrm{Cl} 13.2 \%$. In NMR absence of aromatic protons and presence of a singlet at $\delta 4.6$ for chloromethyl protons agreed with the structure.

2, 3-Dimethoxy-4, 5-methylenedioxyl-1-(1-S-octyl) propylbenzene $(X)$. Isodillapiole (II, $2.2 \mathrm{~g}$ ), octyl mercaptan $(1.5 \mathrm{~g})$ and $p$-toluene sulphonic acid $(100 \mathrm{mg})$ in dry benzene $(100 \mathrm{ml})$ were heated under refiux for $5 \mathrm{hr}$. Working up by washing with water, drying, removing the solvent and purifying by distilling the residue under vacuum afforded $X(3.1 \mathrm{~g})$, bp $111 \sim$ $112^{\circ} \mathrm{C} / 2 \mathrm{~mm}$. Anal. Found: $\mathrm{C}, 65.0 ; \mathrm{H}, 9.2 ; \mathrm{S}, 8.4$. Calcd. for $\mathrm{C}_{20} \mathrm{H}_{32} \mathrm{O}_{4} \mathrm{~S}: \mathrm{C}, 65.2 ; \mathrm{H}, 8.7 ; \mathrm{S}, 8.7 \%$. NMR: $0.89(6 \mathrm{H}, t, J=7 \mathrm{~Hz}$, terminal methyl protons), $1.0 \sim$ $2.0(14 \mathrm{H}, \mathrm{bm}$, methylenic protons), $2.27(2 \mathrm{H}, \mathrm{t}, J=$ $\left.6.5 \mathrm{~Hz},-\mathrm{S} \mathrm{CH}_{2}-\right) ; 3.74\left(3 \mathrm{H}, \mathrm{s} ; \mathrm{OCH}_{3}\right), 4.0(3 \mathrm{H}, \mathrm{s}$, $\left.\mathrm{OCH}_{3}\right), 4.05 \sim 4.25(1 \mathrm{H}, \mathrm{m}, \mathrm{Ar}-\mathrm{CH}-\mathrm{S}), 5.93(2 \mathrm{H}, \mathrm{s}$, methylenedioxy protons), $6.62(1 \mathrm{H}, \mathrm{s}$, Aromatic proton).

2, 3-Dimethoxy-4, 5-methylenedioxy-1-(1-sulphoxy octyl) propylbenzene $(X I)$. The sulphide $(\mathrm{X}, 2.0 \mathrm{~g})$ was kept in acetone $(10 \mathrm{ml})$ containing $\mathrm{H}_{2} \mathrm{O}_{2}(1.5 \mathrm{ml}$, $30 \%$ at room temperature for $12 \mathrm{hr}$. It was then diluted with water $(5 \mathrm{ml})$ and extracted with ether. Removal of solvent and purification gave the product $(1.7 \mathrm{~g})$ as a viscous oil. $\nu_{\max }^{\text {Neat }} 1080 \mathrm{~cm}^{-1}(\mathrm{~S}=\mathrm{O})$. Anal. Found: $\mathrm{C}, 62.3 ; \mathrm{H}, 8.5 ; \mathrm{S}, 8.2$. Calcd. for $\mathrm{C}_{20} \mathrm{H}_{22} \mathrm{O}_{5} \mathrm{~S}: \mathrm{C}, 62.5 ; \mathrm{H} .8 .3 ; \mathrm{S}, 8.3 \%$. NMR spectrum was similar to that of $\mathrm{X}$ and agreed with the structure.

2, 3-Dimethoxy-4, 5-methylenedioxy benzaldehyde $(X I I)$. Isodillapiole (II, $4.4 \mathrm{~g})$ in acetone $(500 \mathrm{ml})$ was stirred with $\mathrm{KMnO}_{4}(6.3 \mathrm{~g})$ in water $(350 \mathrm{ml})$ at room temperature for $4.5 \mathrm{hr}$. The product was isolated by ether extraction of the filtered solution and purified by column chromatography when the aldehyde
(XII, $2.4 \mathrm{~g}$ ) was obtained as colourless needles, mp. $74-5^{\circ}, 2 \underset{\mathrm{max}}{\mathrm{CCl}_{4}} 1680 \mathrm{~cm}^{-1}(\underset{1}{\mathrm{C}=\mathrm{O}})$. Anal. Found: $\mathrm{C}$, 57.2; H, 5.8. Calcd. for $\mathrm{C}_{10} \mathrm{H}_{10} \mathrm{O}_{5}: \mathrm{C}, 57.1 ; \mathrm{H}, 5.7 \%$. NMR: $4.04\left(3 \mathrm{H}, \mathrm{s}, \mathrm{OCH}_{3}\right), 4.13\left(3 \mathrm{H}, \mathrm{s}, \mathrm{OCH}_{3}\right), 6.18$ ( $2 \mathrm{H}, \mathrm{s}$, methylenedioxy protons), $7.14(1 \mathrm{H}, \mathrm{s}$, aldehyde proton). 2, 4-DNPH derivative, orange needles, mp $235 \sim 236^{\circ} \mathrm{C}$.

1-(2, 3-Dimethoxy-4, 5-methylenedioxyphenyl)-non-1ene-3-one $(X I I)$. A mixture of dillapiole aldehyde (XII, $2.2 \mathrm{~g}), 2$-octanone $(1,3 \mathrm{~g})$, methanol $(10 \mathrm{ml})$ and aqueous $\mathrm{NaOH}(45 \% ; 1 \mathrm{ml})$ was stirred at room temperature for $36 \mathrm{hr}$. under nitrogen. Dilution with water, extraction with ether and purification afforded XIII $(2.1 \mathrm{~g})$. It crystallised from pet. ether as light yellow needles, mp $57^{\circ} \mathrm{C}, 2_{\max }^{\mathrm{CHCl}_{3}} 1660 \mathrm{~cm}^{-1} \quad(-\mathrm{C}=\mathrm{C}-$ $\mathrm{C}=\mathrm{O})$. Anal. Found: $\mathrm{C}, 67.7 ; \mathrm{H}, 7.4$. Calcd. for $\mathrm{C}_{18} \mathrm{H}_{24} \mathrm{O}_{0}: \mathrm{C}, 67.5 ; \mathrm{H}, 7.5 \%$. NMR: $0.83(3 \mathrm{H}, \mathrm{t}$, $J=6 \mathrm{~Hz}$, alkyl $\left.\mathrm{CH}_{3}\right), 1.2-2.0(8 \mathrm{H}, \mathrm{bm}$, methylenic protons), $2.73\left(2 \mathrm{H}, t, J=7.5 \mathrm{~Hz}, \mathrm{O}=\mathrm{C}-\mathrm{CH}_{2}-\right), 3.94$ $\left(3 \mathrm{H}, \mathrm{s}, \mathrm{OCH} \underline{\mathrm{H}}_{3}\right), 4.15\left(3 \mathrm{H}, \mathrm{s}, \mathrm{OCH}_{3}\right), 6.16(2 \mathrm{H}, \mathrm{s}$, methylenedioxy protons), $6.77(1 \mathrm{H}, \mathrm{d}, J=17 \mathrm{~Hz}, \mathrm{Ar}-\mathrm{CH}=$ ), $6.99(\mathrm{H}, \mathrm{s}$, aromatic $), 8.09(1 \mathrm{H}, \mathrm{d}, J=17 \mathrm{~Hz}, \mathrm{C}=\mathrm{CH}-$ $\mathrm{C}=\mathrm{O}$ ). 2, 4-DNPH derivative, red plates from ethanol, mp $198 \sim 200^{\circ} \mathrm{C}$.

1-Ethyl-2-methyl-2-(2, 3-dimethoxy-4, 5-methylenedioxyphenyl)-4, 5-methylenedioxy-6, 7-dimethoxy indane $(X I V)$. Isodillapiole $(2.3 \mathrm{~g})$ in ether $(10 \mathrm{ml})$ was stirred at room temperature with $\mathrm{BF}_{\mathrm{g}}$ - etherate $(10 \mathrm{hr})$. The product, isolated by ether extraction after the usual work up, was a brown viscous oil. Column chromatography over silica gel and elution with benzene gave XIV as the major product $(1.8 \mathrm{~g})$ which crystallised from pentane as colourless cubes, mp $86^{\circ} \mathrm{C}$. Anal. Found: $\mathrm{C}, 65.2 ; \mathrm{H}, 6.3 \mathrm{Calcd}$. for $\mathrm{C}_{24} \mathrm{H}_{28} \mathrm{O}_{8}$ : C, $64.9 ; \mathrm{H}, 6.3 \%$. NMR: $0.91(3 \mathrm{H}, t, J=6.5 \mathrm{~Hz}$, $\left.-\mathrm{CH}_{2}-\mathrm{CH}_{3}\right), 1.07\left(3 \mathrm{H}, \mathrm{d}, J=6.5 \mathrm{~Hz},-\mathrm{CH}-\mathrm{CH}_{3}\right), 1.72$ $\left(2 \mathrm{H}, \mathrm{m},-\mathrm{CH}_{2}-\mathrm{CH}_{3}\right), 2.45\left(1 \mathrm{H}, \mathrm{m},-\mathrm{CH}-\mathrm{CH}_{3}\right), 3.32$ $(1 \mathrm{H}, \mathrm{m}, \mathrm{Ar}-\mathrm{CH}-), 3.90\left(3 \mathrm{H}, \mathrm{s},-\mathrm{OCH}_{3}\right), 3.96(3 \mathrm{H}, \mathrm{s}$, $\left.-\mathrm{OCH}_{3}\right), 4.08\left(3 \mathrm{H}, \mathrm{s}, \mathrm{OCH}_{3}\right), 4.18\left(3 \mathrm{H}, \mathrm{s}, \mathrm{OCH}_{3}\right), 4.44$ $(1 \mathrm{H}, \mathrm{d}, J=10.5 \mathrm{~Hz}, \mathrm{Ar}-\mathrm{CH}-\mathrm{Ar}) ; 5.96(2 \mathrm{H}, \mathrm{s}$, methylenedioxy protons), $6.09(2 \mathrm{H}, \mathrm{s}$, methylenedioxy ptotons), 6.4 (1H, s, aromatic proton).

The minor products of this condensation were too small for biological testing and hence were not characterised further.

3-Methyl-5, 6-dimethoxy-7, 8-methylenedioxy-1,2,3, 4-tetrahydronaphthalene-1, 2-dicarboxylic acid dimethyl ester $(X V)$. Isodillapiole (II, $4.4 \mathrm{~g})$ and maleic anhydride $(2.5 \mathrm{~g})$ were heated in xylene for $2.5 \mathrm{hr}$, the solvent removed and excess isodillapiole washed off with petroleum ether. The residue was dissolved in $\mathrm{CH}_{2} \mathrm{Cl}_{2}$, filtered and the adduct precipitated by adding ethanol. It came out of ethanol as colourless plates 
$(2.1 \mathrm{~g}), \mathrm{mp} 206 \sim 208^{\circ} \mathrm{C}, \nu_{\mathrm{max}}^{\mathrm{Nujol}} 3495 \mathrm{~cm}^{-1}(\mathrm{OH})$ and $1850,1780,1720 \mathrm{~cm}^{-1}$ (anhydride).

This intermediate anhydride was refluxed for $6 \mathrm{hr}$. in ethanolic $\mathrm{NaOH}$ and acidified to give the acid $(1.5 \mathrm{~g})$, colourless needles from ethanol, mp $243 \sim 245^{\circ} \mathrm{C}$. The methyl esler $\nu_{\mathrm{max}}^{\mathrm{DHCl}} 1785$ and $1760 \mathrm{~cm}^{-1}(>\mathrm{C}=\mathrm{O})$. Anal. Found: $\mathrm{C}, 58.5 ; \mathrm{H}, 6.5$, Calcd. for $\mathrm{C}_{18} \mathrm{H}_{22} \mathrm{O}_{8}: \mathrm{C}$, $59.0 ; \mathrm{H}, 6.0 \%$.

Bis (2-propyl-3, 4-dimethoxy-5, 6-methylenedioxy phenyl) methane (XVI). A mixture of dihydrodillapiole (III, $4.4 \mathrm{~g}$ ) and $\mathrm{BF}_{3}$-ethereate $(40 \mathrm{ml})$ in $\mathrm{CH}_{2} \mathrm{Cl}_{2}$ $(50 \mathrm{ml})$ was stirred at room temperature for $3 \mathrm{hr}$ and then poured over crushed ice. Extraction with methylene chloride furnished a brown product which was purified by column chromatography over silica gel when XVI ( $3.1 \mathrm{~g})$ was obtained as colorless needles, mp $90 \sim 91^{\circ} \mathrm{C}$, from petroleum ether: benzene $(1: 1)$. Anal. Found: C, 65.5; $\mathrm{H}, 6.8$. Calcd. for $\mathrm{C}_{25} \mathrm{H}_{32} \mathrm{O}_{8}$ : C, $65.2 ; \mathrm{H}, 7.0 \% \mathrm{M}^{+} 460$.

2-Methyl-5, 6-methylenedioxy-7-methoxy dihydrobenzofuran $(X V I I)$. Dillapiole $(\mathrm{I}, 4.5 \mathrm{~g})$ in $\mathrm{CH}_{2} \mathrm{Cl}_{2}$ $(100 \mathrm{ml})$ was saturated with dry $\mathrm{HBr}$ at $0^{\circ} \mathrm{C}$, kept for $24 \mathrm{hr}$, then washed free of acid and the solvent evaporated off. The brown oil obtained, was purified by vacuum distillation to give the benzofuran (XVII) as a colourless liquid $(2.7 \mathrm{~g})$. bp $107^{\circ} \mathrm{C} / 0.3 \mathrm{~mm}$. Anal. Found: $\mathrm{C}, 63.3, \mathrm{H}$, 5.9. Caled. for $\mathrm{C}_{11} \mathrm{H}_{12} \mathrm{O}_{4}: \mathrm{C}$, $63.5 ; \mathrm{H}, 5.8 \%$. NMR: $1.49(3 \mathrm{H}, \mathrm{d}, J=6.5 \mathrm{~Hz}$, $\left.-\mathrm{CH}-\mathrm{CH}_{3}\right), 3.12\left(2 \mathrm{H}, \mathrm{m}, \mathrm{Ar}-\mathrm{CH}_{2}-\right), 4.16(3 \mathrm{H}, \mathrm{s}$, $\left.-\mathrm{OCH}_{3}\right), 5.14\left(1 \mathrm{H}, \mathrm{m},-\mathrm{O}-\mathrm{CH}-\mathrm{CH}_{3}\right), 6.08(2 \mathrm{H}, \mathrm{s}$, methylenedioxy protons), $6.60(1 \mathrm{H}, \mathrm{s}$, aromatic proton).

Bis (2-methyl-5, 6-methylenedioxy-7-methoxy-dihydrobenzofuranyl) methane $(X V I I I)$. The dihydrofuran XVII $(2.1 \mathrm{~g})$ in chloromethyl ether $(10 \mathrm{ml})$ was stirred with $\mathrm{BF}_{3}$ - ethereate $(5 \mathrm{ml})$ at room temperature for $3 \mathrm{hr}$ and poured on crushed ice. The product, isolated by ether extraction, crystallised from ethanol as colourless cubes $(1.6 \mathrm{~g}), \mathrm{mp} 155^{\circ} \mathrm{C}$. Anal. Found: $\mathrm{C}, 64.2 ; \mathrm{H}$, 6.0. Calcd. for $\mathrm{C}_{23} \mathrm{H}_{24} \mathrm{O}_{8}: \mathrm{C}, 64.5 ; \mathrm{H}, 5.6 \% . \mathrm{M}^{+} 428$. NMR: $1.1\left(6 \mathrm{H}, \mathrm{d}, J=6 \mathrm{~Hz}\right.$, two $\left.\mathrm{CH}_{3}\right), 2.38(4 \mathrm{H}, \mathrm{m}$, benzylic protons), 3,54 (2H, s, $\left.\mathrm{Ar}-\mathrm{CH}_{2}-\mathrm{Ar}\right), 3.9(6 \mathrm{H}, \mathrm{s}$, two-OCH $\left.\mathrm{H}_{3}\right), 4.82\left(2 \mathrm{H}, \mathrm{m}\right.$, two- $\left.\mathrm{CH}-\mathrm{CH}_{3}\right), 5.9(4 \mathrm{H}, \mathrm{s}$, two methylenedioxy group protons).

Formulation and bioassay. The synergistic activity of the test compounds was assessed in pyrethrumbased emulsions at insecticides: synergist ratio of $1: 5$ $(w / w)$. Benzene $(10 \%)$ and Tween-80 emulsifier $(0.2 \%)$ were maintained in the spray emulsions. The tests were conducted in three replications of fifteen insects each against 2-3 week-old laboratory reared red flour beetles (Tribolium castaneum Herbst) as reported earlier by Mukerjee et al. ${ }^{12}$ ' The data were subjected to probit analysis ${ }^{13)}$ and factors of synergism ${ }^{14)}$ calculated from $\mathrm{LC}_{50}$ values. Piperonyl butoxide was used as a reference synergist.

\section{RESULTS AND DISCUSSION}

Some derivatives of dillapiole reported in literature (IV, V, VI) were incluaded in these studies for comparision of their synergistic activities. The chloromethyl derivative IX, a possible intermediate for the synthesis of piperonyl butoxide (XIX) type ethers from dillapiole, was an important target in this programme. A synthesis of this chloromethyl derivative has been reported recently ${ }^{8}$ but the compound itself was not isolated and characterised. It has now been fully characterised. However, the yield is poor $(20 \%)$ as the diarylmethane $(\mathrm{XVI})^{8)}$ is invariably the major product of the reaction. Attempts to improve the yield of IX by adopting alternative procedures such as (a) paraformaldehyde $/ \mathrm{HCl}$ (b) $\mathrm{CH}_{2} \mathrm{Cl}_{2} / \mathrm{BF}_{3}$ - ethereate (c) $\mathrm{ClCH}_{2}-\mathrm{OCH}_{3} /$ $\mathrm{AlCl}_{3}$, were not successful. The dimer, XIV, obtained as major product by the action of $\mathrm{BF}_{3}$ - etherate on isodillapiole II, seems to be the $\alpha$-racemate with 1,2-cis-2,3-trans stereochemistry as its NMR spectrum is very similar<smiles>[R2]c1c([R2])c2c(c(OC)c1OC)OCO2</smiles>

\begin{tabular}{|c|c|c|}
\hline No. & $\underline{R_{1}}$ & $\underline{R_{2}}$ \\
\hline$I$ & $H$ & $\mathrm{CH}_{2} \mathrm{CH}=\mathrm{CH}_{2}$ \\
\hline II & H & $\mathrm{CH}=\mathrm{CHCH}_{3}$ \\
\hline III & $H$ & $\mathrm{CH}_{2} \mathrm{CH}_{2} \mathrm{CH}_{3}$ \\
\hline IV & $\mathrm{Br}$ & $\mathrm{CHBrCHBrCH}_{3}$ \\
\hline$v$ & $\mathrm{Br}$ & $\mathrm{CH}_{2} \mathrm{CHBrCH}_{2} \mathrm{Br}$ \\
\hline$v t$ & $H$ & $\mathrm{CHErCHBrCH} 3$ \\
\hline VII & Br & $\mathrm{CH}_{2} \mathrm{CH}_{2} \mathrm{CH}_{3}$ \\
\hline VIII & $H$ & $\mathrm{CH}_{2} \mathrm{CH}(\mathrm{SCN}) \mathrm{CH}_{2} \mathrm{SCN}$ \\
\hline IX & $\mathrm{CH}_{2} \mathrm{Cl}$ & $\mathrm{CH}_{2} \mathrm{CH}_{2} \mathrm{CH}_{3}$ \\
\hline$x$ & $H$ & $\begin{array}{l}\mathrm{CHCH}_{2} \mathrm{CH}_{3} \\
1 \\
\mathrm{SC}_{8} \mathrm{H}_{17}\end{array}$ \\
\hline$X I$ & $H$ & $\begin{aligned} & \mathrm{CHCH}_{2} \mathrm{CH}_{3} \\
1 & \stackrel{\mathrm{SC}_{8} \mathrm{H}_{17}}{ }\end{aligned}$ \\
\hline$X I I$ & $H$ & $\mathrm{CHO}$ \\
\hline XIII & $H$ & $\mathrm{CH}=\mathrm{CHCOC}_{6} \mathrm{H}_{13}$ \\
\hline
\end{tabular}




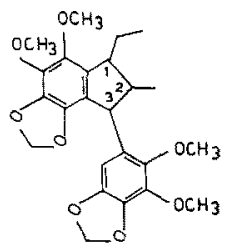

XIV

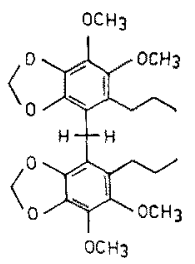

xv!

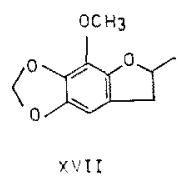

to related compounds reported by MacMillan et $a l .{ }^{15}$, The Diels-Alder adduct derived product (XV) was a mixture of racemates and was used directly is bioassay experiments.

In bioassay studies none of these test chemicals showed any significant insecticidal effect up to $1 \%$ level. The results of their synergistic activity are reported in Table I. As synergists these fall in three categories. In the first group the bromo-derivatives IV, V, VI, VII, the bismethane derivatives XVI and XVIII, the indane derivative XIV and the $S$-octyl ether $\mathrm{X}$ showed poor activity inspite of being mdp derivatives. Compounds possessing two and more mdp groups, XIV, XVI, and XVIII are poorer synergists as has been noted earlier. ${ }^{16}$, The $O$-alkyl ethers corresponding to XI have been reported ${ }^{9}$ to have high activity. It is interesting to note that the change from $O$ to $S$ in these ethers reduces the activity rather very strongly. The thiocyanate VIII on the other hand is a good synergist and together with the chloromethyl ether IX, the sulphoxide
Table I. Synergistic Efficacy of Various Test Chemicals

\begin{tabular}{cccc}
\hline $\begin{array}{c}\text { Structure } \\
\text { No. }\end{array}$ & $\begin{array}{c}\text { Factor of } \\
\text { Synergism }\end{array}$ & $\begin{array}{c}\text { Structure } \\
\text { No. }\end{array}$ & $\begin{array}{c}\text { Factor of } \\
\text { Synergism }\end{array}$ \\
\hline I & 2.0 & XI & 2.2 \\
II & 2.8 & XII & 1.3 \\
III & 2.2 & XIII & 4.7 \\
IV & 1.1 & XIV & 1.0 \\
V & 1.2 & XV & 2.1 \\
VI & 1.2 & XVI & 1.1 \\
VII & 1.7 & XVII & 5.1 \\
VIII & 3.3 & XVIII & 1.2 \\
IX & 1.8 & XIX & 2.0 \\
X & 1.1 & - & - \\
\hline
\end{tabular}

$\mathrm{XI}$, and the tetrahydronaphthalene dicarboxylic ester XV form the second group of active molecules almost as good as piperonyl butoxide XIX, the standard pyrethrum synergist.

The $\alpha, \beta$-unsaturated ketone XIII and the dihydrobenzofuran XVII, forming the third group, are very active molecules having almost twice the activity of piperonyl butoxide under the usual test conditions. Their commercial possibilities however need further technical development.

\section{REFERENCES}

1) H. Wachs, Science, 105, 530 (1947).

2) M. E. Synerholm, A. Hartzell and V. Cullmann, Contrib. Boyce Thompson Inst., 15, 35 (1947).

3) M. E. Synerholm and A. Hartzell, Contrib. Boyce Thompson Inst., 14, 89 (1945).

4) K. C. Gulati and B. S. Parnar, Indian Patent, $119,536(1969)$.

5) E. P. Lichtenstein, T. T. Liang, K. R. Schulz, H. K. Schnoes and G. T. Karter, J. Agr. Food Chem. 22, 658 (1974).

6) S.S. Tomar, V.S. Saxena, M. L. Maheshwari, Prakash Sarup and S. K. Mukerjee, Indian J. Ent., 40, 113 (1978).

7) Y. P. Talwar, J. B. Srivastava and M. C. Nigam, Indian Perfumer, 10, 43 (1966).

8) B. P. Saxena, Opender Kaul, S. C. Gupta, A. K. Kalla, K. L. Dhar and C. K. Atal, Pyrethrum Post, 14, 41 (1977).

9) S. S. Tomar, M. L. Maheshwari and S. K. Mukerjee, J. Agr. Food Chem., 27, 547 (1979).

10) C. Ciamician and P. Sliber, Berichte, 29, 1799 (1896).

11) J. L. Wood and L. F. Fieser, J. Am. Chem. Soc., 63, 2323 (1941). 
12) S. K. Mukerjee, B.S. Parmar, N. K. Roy and R. P. Singh, Indian J. Agr. Sci., 436, 516 (1973).

13) D. J. Finney, Probit Analysis Edt. 3, Cambridge University Press, Cambridge. p. 318 (1971).

14) P. R. Chadwick, Pyrethrum Post, 7, 25 (1963).
15) J. MacMillan, I. L. Martin and D. J. Morris, Tetrahedron, 25, 905 (1969).

16) M. E. Synerholm, A. Hartzell and J. M. Arthur, Contrib. Boyce Thompson Inst, 13, 433 (1945). 